\title{
A Review on Importance of Artocarpus heterophyllus L. (Jackfruit)
}

Ahasan Ullah Khan*, Israt Jahan Ema, Md. Ruman Faruk, Shofiul Azam Tarapder, Anayat Ullah Khan, Sana Noreen and Muhammad Adnan

\begin{tabular}{|c|c|c|c|}
\hline Received : April 26, 2021 & Revised : June 29, 2021 & aly 1,2021 & Online : July \\
\hline \multicolumn{4}{|r|}{$\begin{array}{l}\text { sh. It is widely consumed by most } \\
\text { cument the medicinal significance } \\
\text { a literature review. All parts of the } \\
\text { fruit is the main fruit of the tree, it } \\
\text { anti-diabetic, anti-oxidant, anti- } \\
\text { ylic acids, dietary fiber, vitamins, } \\
\text { and thus meets up nutritional re- } \\
\text { health-promoting effects of jack- }\end{array}$} \\
\hline
\end{tabular}

Keywords: jackfruit, medicinal importance, fruit and seed quality, health benefits, morphology

\section{INTRODUCTION}

Artocarpus heterophyllus is the scientific name of jackfruit which the fruit belong to the family of Moracea and native to Southeast Asia [1] -[3]. It is widely cultivated in most tropical countries like Bangladesh, India, Burma, Philippines, Pakistan, Sri Lanka, Malaysia, Thailand, and several areas in Brazil, Queensland, Africa and some other parts of Australia and America. Bangladesh is sanctified with a vast diversity of fruits. About 70 different types of fruits are grown in Bangladesh [4]. Jackfruit is the national fruit of Bangladesh [5][6] and mango is our national plant of Bangladesh [7]. It is the major fruit tree at Madhupur tract in Bangladesh [8]. The edible fruit of jackfruit is known as the "poor man's food" [9][10]. It is the most popular fruit in rural and urban areas of Bangladesh. It ranks the $4^{\text {th }}$

\section{Copyright Holder:}

(C) Khan, A. U., Ema, I. J., Faruk, M. R., Tarapder, S. A., Khan, A. U., Noreen, S., and Adnan, M. (2021)

\section{First Publication Right:}

Journal of Multidisciplinary Applied Natural Science

\section{Publisher's Note:}

Pandawa Institute stays neutral with regard to jurisdictional claims in published maps and institutional affiliations.

This Article is Licensed Under: position as per production volume after banana, mango, and pineapple [11]. Jackfruit ranks the $3^{\text {rd }}$ position with respect to fruit production in Bangladesh.

There are so many benefits from the fruit, tree, branches of jackfruit. The fruit is enriched with a diverse of nutrients and edible where the fruit can be consumed when its ripe and when its green part uses as vegetable. The edible bulbs of ripe jackfruit are usually consumed fresh or processed into canned products; $10-15 \%$ of the total fruit weight is considered as its seed weight. In Asia, folk consume the plants in medicine and used as anti-bacterial, anti-diabetic, anti-oxidant, anti-inflammatory, and anti-helmintics agents [12]. Approximately, 2 MegaJoule energy per $\mathrm{kg} /$ wet weight of ripe perianth is required for the fruit processing. Besides, the fruit can supply bioactive compounds [13]. Phytonutrients contain in jackfruit such as lignans, flavones, and saponins exhibit anti-cancer, anti-ulcer, anti-hypertensive, and anti-aging activities [14]. The fruit is rich in carbohydrates, minerals, carboxylic acids, dietary fiber, vitamins, and minerals. The seed is rich in manganese, magnesium, potassium, calcium iron, and lectins and thus meets up nutritional requirements for the rural people. The jackfruit seed flour is not only a rich source of protein, starch and dietary fibers but can also be regarded as an abundant yet cheap source of nutrients. Lectin, a class of glycoprotein found in jackfruit seed, has been reported to possess 
Table 1. Keyword search.

\begin{tabular}{clc}
\hline No. & Keyword Search & Articles Number \\
\hline 1 & Artocarpus heterophyllus L. or Jackfruit & 215 \\
2 & Medicinal importance & 188 \\
3 & Fruit and seed quality & 218 \\
4 & Health benefits & 114 \\
5 & Morphology & 225 \\
6 & Limit of article & 201 \\
7 & Manually screened & 87 \\
8 & Articles included in the review & 60 \\
\hline
\end{tabular}

anti-bacterial, anti-fungal, and anti-carcinogenic properties [15]. Ripe jackfruit pulp is processed, dehydrated and sold as dry powder which is utilized for juice, biscuits, chutney, jam, jelly, toffee, paste, leather, bar, nectar, squash, and pickle [16]. It is also canned in syrup, either plain or blended with dehydrated bulbs, chutney, preserves, candy, concentrate and powder. Now a days, consumer preferences have changed to diets with more natural antioxidants, dietary fibers, natural colorants, minerals, vitamins, reduced calories, low cholesterol, low sugar, free of chemicals, etc. The possibilities of utilizing jackfruit waste and by product of leaves and wood for production of biogas, briquettes and biochar [17]. Jackfruit growth and development are directly depended on the source of nutrients and those nutrients improve the nutritional quality of jackfruit [18].

The qualitative jackfruit and some seeds are exported to UK [19]. The jackfruit is a cross pollinated fruit tree and is mainly propagated by seeds [20]. The tree as well can provide many other uses in environmental protection. The leaves of the jackfruit tree are used as nutritious food for cattle. The leaves are rich in vitamins and minerals which are important for the animal. Its remaining stalks are used as wood. However, the main stem enhances the beauty of the house as furniture. It is possible to earn income by selling wood as wood, just as it is possible to make a lot of profit by selling well shape wood. However, a lot of money is earned by selling ordinary jackfruit fruits. But the jackfruit trees cultivated around the village house are not taken care of since no fertilizer is given. By considering the above points, the present study was undertaken to collect information about the significance of the nutritional and medicinal importances of jackfruit in Bangladesh.

\section{METHODOLOGY}

To assess the current state of the research on importance of jackfruit, a review of the existing journal literature, books, report, blogs, and newspaper were carried out. Keywords (jackfruit, medicinal importance, fruit and seed quality, health benefits, and morphology) search in the google, google scholar, web of science database (www.thomsonreuters.com/web-of-science), and a full-text search of the Science Direct (www.sciencedirect.com) database were carried out. Information was also collected from government organization and NGO's by personal communication. The reviews or literature reviews will be examined to identify further studies for inclusion, and the results of meta-analyses will not be included in the analysis.

\section{MORPHOLOGY OF JACKFRUIT}

\subsection{Size and Shape}

Jackfruit grow as an evergreen tree that has a relatively short trunk with a dense treetop. It easily reaches heights of 10 to $20 \mathrm{~m}$ (33 to 66 feet) and trunk diameters of 30 to $80 \mathrm{~cm}$ (12 to 31 inches). The canopy shape is usually conical or pyramidal in young trees and becomes spreading and domed in older trees (Figure 1). It sometimes forms buttress roots. The bark of the jackfruit tree is reddishbrown and smooth. In the event of injury to the bark, a milky juice is released. In young trees, the leaf edges are irregularly lobed or split. The tree casts a very dense shade. Heavy side branching usually begins near the ground. All parts of the tree 
exude sticky white latex when injured.

\subsection{Flowers}

This species is monoecious, having male and female inflorescences (or "spikes") on the same tree. The flowers are small, sitting on a fleshy rachis. Male and female spikes are borne separately on short, stout stems that sprout from older branches and the trunk. The male flowers are greenish, some flowers are sterile (Figure 1). Male spikes are found on younger branches above female spikes. Male spikes are dense, fleshy, cylindrical to club shaped, and up to $10 \mathrm{~cm}$ (4 in) in length. Flowers are tiny, pale green when young, turning darker with age. The male flowers are less and small hairy and the perianth ends with two 1 to $1.5 \mathrm{~mm} \mathrm{(3/64}$ to $1 / 16$ in) membrane. After the pollen distribution, the stamens become ash-gray and fall off after a few days.

Female flowers are larger, elliptic or rounded, tubular calyx, with hairy and tubular perianth, have a fleshy flower-like base. The female flowers contain an ovary with a broad, capitate or rarely bilobed scar (Figure 1). The flowers are reportedly pollinated by insects and wind, with a high percentage of crosspollination. The blooming time ranges from December until February or March [21].

\subsection{Fruit}

The inflorescences are formed on the trunk, branches or twigs (cauliflory). Jackfruit trees are monoecious, having both female and male flowers on a tree. Fruit of jackfruit has a compound or multiple fruit with a green to yellow brown exterior rind that is composed of hexagonal, bluntly conical carpel apices that cover a thick, rubbery, whitish to yellowish wall (Figure 1). The ellipsoidal to roundish fruit is a multiple fruit formed from the fusion of the ovaries of multiple flowers. The fruits grow on a long and thick stem on the trunk. The heavy fruit is held together by a central fibrous core. They vary in size and ripen from an initially yellowish-green to yellow, and then at maturity to yellowish-brown. They possess a hard, gummy shell with small pimples surrounded with hard, hexagonal tubercles. The large and variously shaped fruit have a length of 30 to $100 \mathrm{~cm}$ (10 to 40 inches) and a diameter of 15 to $50 \mathrm{~cm}$ (6 to 20 inches) and can weigh $10-25 \mathrm{~kg}$ (22-55 pounds) or more [22].

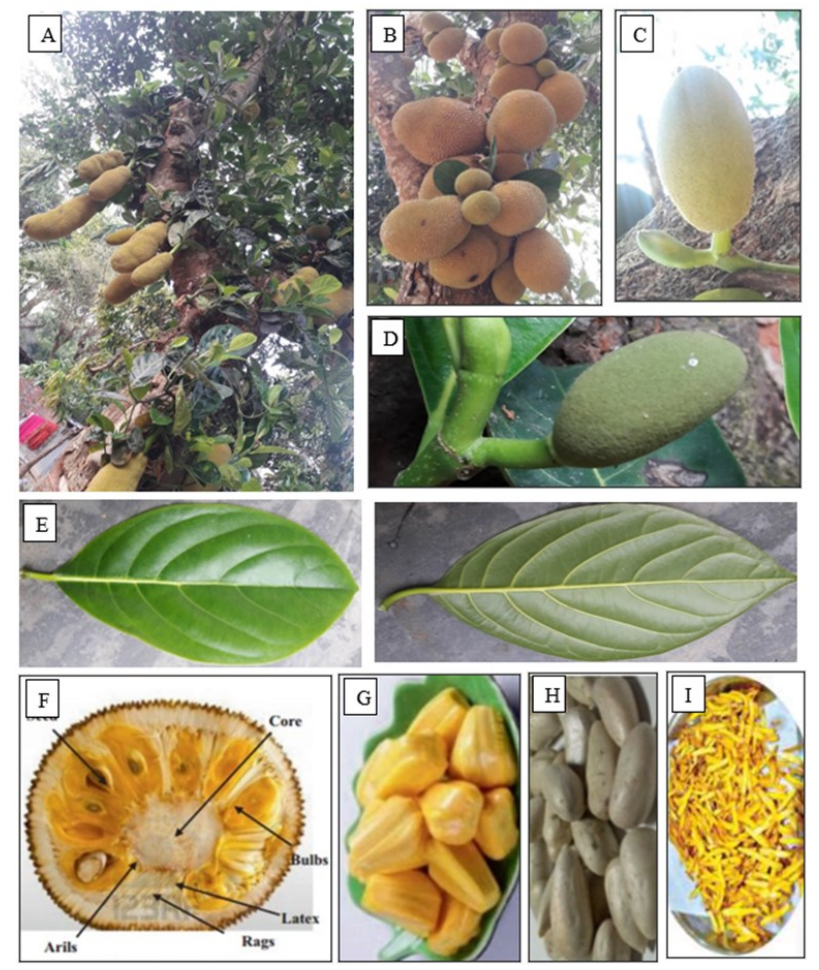

Figure 1. (a) Jackfruit tree with the fruits; (b) jackfruit tree with the fruits in different stages of fruiting; (c) club shaped spike male inflorescence; (d) female inflorescence; (e) leaf showing both side (f) Cut section of jackfruit; (g) the bulbs of jackfruit; (h) the jackfruit seed and (i) Jackfruit Chips. 


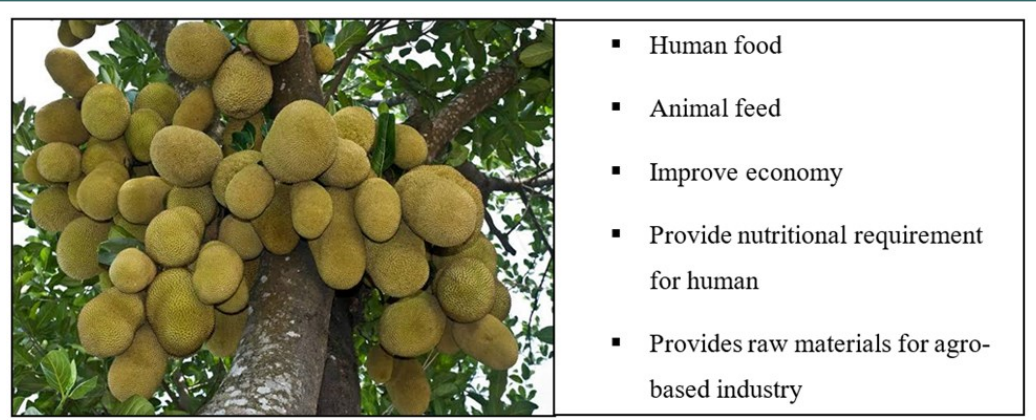

Figure 2. Diversified uses of Jackfruit plant, fruits and by products [30].

\subsection{Leaves}

Leaves are dark green, alternate, entire, simple, glossy, leathery, stiff, large (up to $16 \mathrm{~cm}$ [6 in] in length), and elliptic to oval in form. The leaves are alternate and spirally arranged (Figure 1). They are gummy and thick and are divided into a petiole and a leaf blade. On older trees, the leaves are rounded and dark green, with a smooth leaf margin. The petiole is 2.5 to $7.5 \mathrm{~cm}$ ( 1 to 3 inches) long. The leathery leaf blade is 20 to $40 \mathrm{~cm}$ ( 7 to 15 inches) long, and 7.5 to $18 \mathrm{~cm}$ ( 3 to 7 inches) wide and is oblong to ovate in shape. Leaves are often deeply lobed when juvenile and on young shoots.

\subsection{Seeds}

Seeds are light brown, rounded, $2-3 \mathrm{~cm}(0.8-1.2$ in) in length by $1-1.5 \mathrm{~cm}(0.4-0.6 \mathrm{in})$ in diameter, and enclosed in a thin, whitish membrane. There may be about 100-500 seeds per fruit (Figure 1). Seeds are recalcitrant and can be stored up to a month in cool and humid conditions [21]. The seed coat consists of a thin, waxy, parchment-like and easily removable testa (husk) and a brownish, membranous tegmen. The cotyledons are usually unequal in size, and the endosperm is minimally present. An average fruit consists of $27 \%$ edible seed coat, $15 \%$ edible seeds, $20 \%$ white pulp (undeveloped perianth, rags) and bark, and 10\% core [7].

\section{MAJOR PARTS OF A JACKFRUITS}

Jackfruit has three main parts [2], the fruit axis, the perianth and the bulbs. The axis contains the core, latex and the arils (Figure 1). Jackfruit has lactiferous cells which are responsible for production of latex [23], which is sap that sticky in nature. The perianth contains the rind and the rags, the bulbs contain the edible part and the seeds. The inedible parts of jackfruit include prickly rind, non- edible perianth and a central core [24]. All these inedible jackfruit parts are potential raw materials for bioenergy and biochar production.

\section{USES OF THE JACKFRUIT PARTS}

All parts of the fruit and tree are used as human food, animal feed and wood source for furniture (Figure 2). The jackfruit pulp is processed for juice, biscuits, chutney, jam, jelly, toffee, paste, leather, bar, nectar, squash and pickle. The color and flavor are important for the jackfruit bulb [25]. Ice-cream prepared by using the jackfruit bulbs. The green fruit bulbs and seeds used as cooking materials in the farmers community. The leaves use as animal feed and the leaves are contain significant amount of nutrients. The wood materials are using as furniture of home and possibilities of utilizing jackfruit waste and by product of leaves and wood for production of biogas, briquettes and biochar which is applied in the farmer's field. The jackfruit bulbs are using in bakery industry which is improve the food quality. The bakery products are increasingly gaining popularity since they are convenient, readily available in diverse tastes and textural profiles, less expensive and possess high nutritive value. The bakery products such as biscuits [26], cookies, bread [27], cake [28], and muffins [29]. have been formulated by supplementation with different levels of jackfruit seed flour. Therefore, there is scope to develop the industry which is help in employment sector in Bangladesh.

\section{MEDICINAL SIGNIFICANCE OF JACKFRUIT}

The Artocarpus species have been used as traditional medicines. The plants have been used as anti-bacterial, anti-diabetic, antioxidant, anti- 
inflammatory, and anti-helminthic agents [31] Jackfruit is also a rich source of many minerals such as $\mathrm{N}, \mathrm{P}, \mathrm{K}, \mathrm{Ca}, \mathrm{Mg}, \mathrm{S}, \mathrm{Zn}, \mathrm{Cu}$, etc. [32]. The nutritional parameters of the jackfruit flesh, seeds and the meal are presented in Table 2. The water contents of the young, ripe fruit and seeds were in a range of $51.0-94.4 \mathrm{~g}$. The available digestible carbohydrate contents of the young, ripe fruit and seeds were in a range of 16.0-38.40 g. Jackfruit seeds are underutilized and less acknowledged by people, but they have considerable nutritional benefits and constitute about $10 \%$ to $15 \%$ of the fruit weight [33]. The protein content of the meal was $0.40-2.60 \mathrm{~g}$ in the young, ripe fruit and seeds of jackfruit, with a higher contribution from the young fruit while the fat content of the meal was 0.10 $0.60 \mathrm{~g}$. The fiber content of the meal was $1.0-2.60$ $\mathrm{g}$ in the young, ripe fruit and seeds of jackfruit with a higher contribution from the young fruit while the mineral content of the meal was $0.87-0.90 \mathrm{~g}$. The ripe fruit contains $20.60 \mathrm{~g}$ sugar in the meal. The jackfruit rich in calcium, magnesium, phosphorus, potassium, sodium, iron, vitamin A, thiamine, riboflavin and vitamin $\mathrm{C}$ (Table 2). Jack seeds contained high total dietary fiber (TDF) (11.1\%) compared to flesh (2.6\%). Jackfruit seeds also contained $8 \%$ resistant starch (undigestible starch).

It is a major source of carbohydrates, minerals and vitamins [34]. Hasan et al. [35] reported that the average annual net returns found more than the agriculture system. Alves et al. [36] observed that the fruit contains lignins, flavones and saponins which have the properties of anti-cancer, anti-ulcer, anti-hypertensive, and anti-aging. It contains immense medicinal values and also considered a rich source of carbohydrates, minerals, carboxylic acids, dietary fiber, and vitamins such as ascorbic acid and thiamine [13]. Manganese, magnesium [32], potassium, calcium, and iron [37] elements are found in seed. Mukprasirt and Sajjaanantakul [38] reported that the seeds contain lectins as jacalin and artocarpin. Jacalin has been shown to be useful for the evaluation of the immune status of patients infected with human immunodeficiency virus [39]. Seed nanoparticles were found effective against Escherichia coli and Bacillus megaterium bacteria [40]. It has anti-oxidant action [3], and acts against inflammation, malarial fever and skin diseases [41], it also shown, anti-bacterial and anti-helminthic activities [42]. The tree leaves are commonly used as healing for ulcer. Its leaves have the potential of curing diabetics due to the presence of hypoglycemic and hypolipidemic substances [43]. The leaves and stems have sapogenins, cyclooctenone, cycloartenol, $\beta$-sitosterol and tannins. The latex yield artosteron mixed with vinegar promotes healing of glandular swelling and snake bites [44]. Long et al. [45] reported that the

Table 2. Nutrient composition of jackfruit (100 g edible portion).

\begin{tabular}{lccc}
\hline \multicolumn{1}{c}{ Nutrients } & Young fruit & Ripe fruit & Seed \\
\hline Water $(\mathrm{g})$ & $76.2-85.2$ & $72.0-94.0$ & $51.0-64.50$ \\
Protein $(\mathrm{g})$ & $2.00-2.60$ & $1.20-1.90$ & $0.40-0.43$ \\
Fat $(\mathrm{g})$ & $0.10-0.60$ & $0.10-0.40$ & $0.40-0.43$ \\
Carbohydrate $(\mathrm{g})$ & $9.40-11.5$ & $16.0-25.4$ & $25.8-38.4$ \\
Fiber $(\mathrm{g})$ & $2.60-3.60$ & $1.0-1.50$ & $1.0-1.50$ \\
Sugar $(\mathrm{g})$ & - & 20.6 & - \\
Minerals (g) & 0.90 & $0.87-0.90$ & $0.90-1.20$ \\
Calcium (mg) & $30.0-73.2$ & $20.0-37.0$ & 50.0 \\
Magnesium (mg) & - & 27.0 & 54.0 \\
Phosphorus (mg) & $20.0-57.2$ & $38.0-41.0$ & $38.0-97.0$ \\
Potassium (mg) & $287-323$ & $191-407$ & 246 \\
Sodium (mg) & $3.00-35.0$ & $2.0-41.0$ & 63.2 \\
Iron (mg) & $0.40-1.90$ & $0.50-1.10$ & 1.50 \\
Vitamin A (IU) & 30 & $175-540$ & $10.0-17.0$ \\
Thiamine (mg) & $0.05-0.15$ & $0.03-0.09$ & 0.25 \\
Riboflavin (mg) & $0.05-0.20$ & $0.05-0.40$ & $0.11-0.30$ \\
Vitamin C (mg) & $12.0-14.0$ & $7.00-10.0$ & 11.0 \\
\hline Source: Goswami and Chacrabati [34] & & & \\
\hline
\end{tabular}




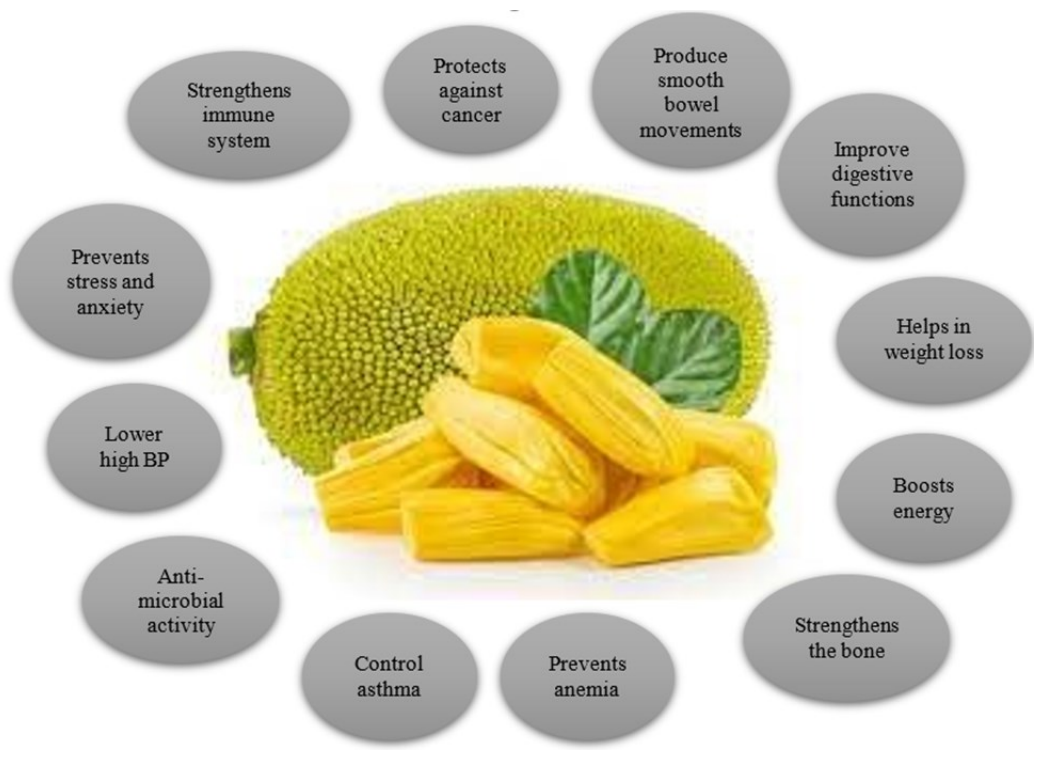

Figure 3. Health benefits of jackfruit.

root extract is a therapy for asthma and skin disorder. The wood has sedative property and believed that it may cause promotion of abortioncure diarrhea and fever [46]. The fruits and roots are used for tapeworm infection [47]-[49]. The fruit is rich in carbohydrates, complex B vitamins, and minerals [50]. The freshly fruit is consumed and can be processed to candies, sweeties, frozen pulps, juices and vegetable in immature fruit. Its seed can be consumed as baked or used in culinary to develop several menus. Now, there are studies concerning the use of seed meal for preparing cookies, sweeties and bread as an alternative source of carbohydrate. The jackfruit contains variable constituents of moisture $(6.7 \%)$, glucosides $(38.0 \%)$, lipids $(0.7 \%)$, protein $(1.7 \%)$ and cellulose (59.0\%) [50]. Jagtap and Bapat [51] observed that the ripe fruits are rich in nutritive value; every $100 \mathrm{~g}$ of ripe fruit contains $287-323$ $\mathrm{mg}$ potassium, 30.0-73.2 $\mathrm{mg}$ calcium and 11-19 g carbohydrates. Chowdhury et al. [52] reported that the bark contains betullic acid and a flavone pigment, cycloheterophyllin $\left(\mathrm{C}_{30} \mathrm{H}_{30} \mathrm{O}_{7}\right)$. The fruit pulp also contains lycopene [53]. De-Faria et al. [54] reported that the fruit contain 18 carotenoids and they were successfully separated, identified, and quantified. The leaves and stem contain sapogenins, cycloartenone, cycloartenol, $\beta$ sitosterol, and tannins thus showing estrogenic activity. A root contains $\beta$-sitosterol, ursolic acid, betulinic acid, and cycloartenone [4]. Jackfruit seed contains a thin brown spermoderm, the crude fiber $(2.36 \%)$, but the composition of flour depends on nature of seed [55].

\section{HEALTH BENEFITS OF JACKFRUIT SEEDS}

The phytonutrients such as lignans, saponins, and isoflavones present in the seeds, plays beneficial role in human health presented in Figure 3 [55]. The presence of high fiber content (3.6 $\mathrm{g} / 100 \mathrm{~g}$ ) in the jackfruit improve digestion system and produces smooth bowel movements. It also offers protection to the colon mucous membrane by removing carcinogenic chemicals from the large intestine [30].

The addition of the jackfruit seed flour to deepfried products results in a reduction in fat absorption up to a certain limit [56]. The seeds are rich in dietary fiber and B-complex vitamins. Due to their high fiber content, they help lower the risk of heart disease, prevent constipation and promote weight loss. Jackfruit seeds also contain resistant starch, which controls blood sugar and keeps the gut healthy. Jackfruit seeds possess anti-microbial activity, which prevents foodborne diseases [54]. The seeds contain an important lectin known as jacalin, used as a tool to evaluate the immune system of an HIV infected person. In China, the seeds are known to be beneficial in overcoming the toxicity due to alcohol and likewise. Meanwhile, in India, the seeds are a crucial component of an antidote produced for heavy drinkers [57]. The seeds contain an abundance of magnesium which plays a vital role in lowering the blood pressure and 
maintaining bone health since it aids in calcium absorption and hence helps to strengthen the bones [2]. Furthermore, the seeds are rich in highly soluble protein resulting in the prevention and treatment of mental stress and anxiety. The seeds have low water and fat-absorption capacities, which helps in prevention of obesity [58]-[60].

\section{CONCLUSIONS}

Jackfruit is quite versatile. It can be eaten raw, cooked, ripe or unripe and tastes great in a variety of sweet and savory dishes. The consumption of jackfruit has grown in recent years due to its reported health benefits. Jackfruit and its pulp and seeds are rich sources of several high-value compounds with potential beneficial health benefits. The rich bioactive profile of jackfruit makes it a highly nutritious and desirable fruit crop. The review concluded that all the nutrients like vitamins and minerals may fulfill the malnutrition problem in the rural area of Bangladesh.

\section{AUTHOR INFORMATION}

\section{Corresponding Author}

Ahasan Ullah Khan - Department of
Entomology, Sylhet Agricultural University,
Sylhet-3100 (Bangladesh); Department of
Agroforestry and Environmental Science, Sylhet
Agricultural University, Sylhet-3100
(Bangladesh);
orcid.org/0000-0002-7029-8215
Email: ahasanullahsau@gmail.com

\section{Authors}

Israt Jahan Ema - Department of Plant Pathology and Seed Science, Sylhet Agricultural University, Sylhet-3100 (Bangladesh);

Md. Ruman Faruk - Department of Agricultural Extension Education, Sylhet Agricultural University, Sylhet-3100 (Bangladesh);

Shofiul Azam Tarapder - Department of Agronomy and Haor Agriculture, Sylhet Agricultural University, Sylhet-3100 (Bangladesh);

Anayat Ullah Khan - Department of Mathematics, Jashore University of Science and Technology, Jashore-7408 (Bangladesh);
(1) orcid.org/0000-0001-7447-4864

Sana Noreen - University Institute of Diet and Nutritional Sciences, The University of Lahore, Punjab-54000 (Pakistan);

orcid.org/0000-0002-4040-5454

Muhammad Adnan - Department of Agronomy, University of Sargodha, Punjab40100 (Pakistan);

(D) orcid.org/0000-0002-7582-4675

\section{CONFLICT OF INTEREST}

The authors declare that there is no conflict of interest.

\section{REFERENCES}

[1] B. O. Ajiboye, O. Adeleke Ojo, O. Adeyonu, O. Imiere, B. Emmanuel Oyinloye, and O. Ogunmodede. (2018). "Ameliorative activity of ethanolic extract of artocarpus heterophyllus stem bark on alloxan-induced diabetic rats". Advanced Pharmaceutical Bulletin. 8 (1): 141-147. $\underline{10.15171 /}$ apb.2018.017.

[2] R. A. S. N. Ranasinghe, S. D. T. Maduwanthi, and R. A. U. J. Marapana. (2019). "Nutritional and health benefits of jackfruit (Artocarpus heterophyllus lam.): a review". International Journal of Food Science. $2019 \quad$ : $\quad 1-12$. 10.1155/2019/4327183.

[3] A. K. Gupta, M. A. Rather, A. Kumar Jha, A. Shashank, S. Singhal, M. Sharma, U. Pathak, D. Sharma, and A. Mastinu. (2020). "Artocarpus lakoocha Roxb. and Artocarpus heterophyllus Lam. Flowers: New Sources of Bioactive Compounds". Plants. 9 (10): 1329. 10.3390/plants9101329.

[4] R. Uddin, M. U. Thakur, M. Z. Uddin, and G. M. R. Islam. (2021). "Study of nitrate levels in fruits and vegetables to assess the potential health risks in Bangladesh". Scientific Reports. 11 (1): 4704. 10.1038/ s41598-021-84032-z.

[5] M. A. Rahaman, A. Rahman, M. G. Miah, M. A. Hoque, and M. M. Rahman. (2018). "Productivity and profitability of jackfruiteggplant agroforestry system in the terrace ecosystem of Bangladesh". Turkish Journal 
of Agriculture - Food Science and Technology. 6 (2): $124 . \quad \underline{10.24925 /}$ turjaf.v6i2.124-129.1330.

[6] S. Sarkar. (2017). "Jackfruit production in Tripura: a land for trip of jackfruits in Bangladesh". the Asian Journal of Horticulture. 12 (1): 88-90. 10.15740/has/ tajh/12.1/88-90.

[7] A. U. Khan. (2020). "Status of mango fruit infestation at home garden in Mymensingh, Bangladesh". Current Research in Agriculture and Farming. 1 (4): 35-42. 10.18782/2582-7146.119.

[8] M. Sazib Uddin, M. Najmus Sayadat Pitol, and S. M Feroz. (2021). "Floristic composition and woody species diversity in National Park of Madhupur tract under Tangail North Forest division, Bangladesh". Journal of Forests. 8 (1): 99-108. 10.18488/ journal.101.2021.81.99.108.

[9] M. Balaji Rajkumar, B. Gundappa, M. M. Tripathi, and S. Rajan. (2018). In: "Omkar O (Ed) Pests and their management". Springer Singapore, Singapore. 10.1007/978-981-10$\underline{8687-8 \quad 18 .}$.

[10] G. S. Chikkanna. (2021). "Technical Facts on the Current Scenario and Future Potential of Jackfruit Processing". Research Biotica. 3 (2): 94-106.

[11] C. Saha, H. Mahmood, S. N. S. Nayan, M. R. H. Siddique, S. M. R. Abdullah, S. M. Z. Islam, M. Z. Iqbal, and M. Akhter. (2021). "Allometric biomass models for the most abundant fruit tree species of Bangladesh: A Non-destructive approach". Environmental Challenges. 3 : 100047. $\underline{10.1016 /}$ j.envc.2021.100047.

[12] A. U. Khan, M. A. R. Choudhury, M. A. Maleque, C. K. Dash, M. S. A. Talucder, A. R. M. Maukeeb, I. J. Ema, M. Adnan. (2021). "Management of insect pests and diseases of jackfruit (Artocarpus heterophyllus 1.) in agroforestry system: a review". Acta Entomology and Zoology. 2 (1): $37-46$.

10.33545/27080013.2021.v2.i1a.29.

[13] S. B. Swami and S. B. Kalse. (2018). In: "Mérillon J and Ramawat K (eds) Bioactive molecules in food". Springer Cham, New
York. 10.1007/978-3-319-54528-8 87-1.

[14] S. Palamthodi, S. Shimpi, and K. Tungare. (2021). "A study on nutritional composition and functional properties of wheat, ragi and jackfruit seed composite flour". Food Science and Applied Biotechnology. 4 (1): 63. 10.30721/fsab2021.v4.11.107.

[15] A. N. M. Ramli, S. Z. S. Badrulzaman, H. A. Hamid, and P. Bhuyar. (2021). "Antibacterial and antioxidative activity of the essential oil and seed extracts of Artocarpus heterophyllus for effective shelflife enhancement of stored meat". Journal of Food Processing and Preservation. 45 (1). 10.1111/jfpp.14993.

[16] Y. Li, X. Duan, S. Liu, Y. Li, X. Zhang, and C. Ye. (2017). "Changes in soluble sugar accumulation and activities of sucrosemetabolizing enzymes during fruit ripening of jackfruit". Journal of Agricultural Science. 9 (8): 155. 10.5539/jas.v9n8p155.

[17] D. Nsubuga, N. Banadda, I. Kabenge, and K. D. Wydra. (2020). "Potential of jackfruit waste for biogas, briquettes and as a carbondioxide sink-a review". Journal of Sustainable Development. 13 (4): 60. $\underline{10.5539 / \text { jsd.v13n4p60. }}$.

[18] M. D. Toor. (2021). "Nutrients and their importance in agriculture crop production: a review". Indian Journal of Pure \& Applied Biosciences. 9 (1): 1-6. 10.18782/2582$\underline{2845.8527 .}$.

[19] Z. Al Riyadh, M. A. Rahman, M. G. Miah, S. R. Saha, M. A. Hoque, M. M. Rahman, and I. Miyajima. (2020). "Performance of spices as lower-storey crop in jackfruitpapaya multistorey agroforestry system in Bangladesh". Journal of the Faculty of Agriculture, Kyushu University. 65 (2): $223-$ 231. 10.5109/4103694.

[20] C. Witherup, M. I. Zuberi, S. Hossain, and N. J. C. Zerega. (2019). "Genetic diversity of bangladeshi jackfruit (Artocarpus heterophyllus) over time and across seedling sources". Economic Botany. 73 (2): 233248. 10.1007/s12231-019-09452-5.

[21] E. M. Gardner, R. J. Gagné, P. E. Kendra, W. S. Montgomery, R. A. Raguso, T. T. McNeil, and N. J. C. Zerega. (2018). "A 
flower in fruit's clothing: pollination of jackfruit (Artocarpus heterophyllus, Moraceae) by a new species of gall midge, Clinodiplosis ultracrepidata sp. nov. (diptera: cecidomyiidae)". International Journal of Plant Sciences. 179 (5): 350-367. 10.1086/697115.

[22] S. S. Rana, R. C. Pradhan, and S. Mishra. (2018). "Variation in properties of tender jackfruit during different stages of maturity". Journal of Food Science and Technology. 55 (6): 2122-2129. 10.1007/s13197-018-31279.

[23] S. Bhadra, N. Mohan, G. Parikh, and S. Nair. (2019). "Possibility of artocarpus heterophyllus latex as an alternative source for natural rubber". Polymer Testing. 79 : 106066.

$\underline{10.1016 /}$

j.polymertesting.2019.106066.

[24] S.-Y. Xu, J.-P. Liu, X. Huang, L.-P. Du, F.L. Shi, R. Dong, X.-T. Huang, K. Zheng, Y. Liu, and K.-L. Cheong. (2018). "Ultrasonicmicrowave assisted extraction, characterization and biological activity of pectin from jackfruit peel". Lebensmittel Wissenschaft and Technologie. 90 : $577-$ 582. 10.1016/j.lwt.2018.01.007.

[25] V. L. Shinde, C. D. Pawar, O. S. Warang, V. S. Dandekar, M. M. Kulkarni, J. Josiya and M. S. Joshi. (2021). "Studies on preparation of ice-cream from jackfruit (Artocarpus heterophyllus) seed powder," International Journal of Chemical Studies. 9 (1): 27102712. 10.22271/chemi.2021.v9.i1al.11636.

[26] K. R. Barge and S. P. Divekar. (2018). "Development of coconut milk residue and jackfruit seed enriched biscuit". International Journal of Agricultural Engineering. 11 (2): 373-378. 10.15740/ HAS/IJAE/11.2/373-378.

[27] V. Tulyathan, K. Tananuwong, P. Songjinda, and N. Jaiboon. (2002). "Some physicochemical properties of jackfruit (Artocarpus heterophyllus Lam) seed flour and starch". ScienceAsia. 28 (1): 37. 10.2306/scienceasia1513-1874.2002.28.037.

[28] M. Haque, R. Begum, A. Shibly, M. Sultana, and A. Khatun. (2015). "Influence of jackfruit pulp on the quality and shelf life of jackfruit cake". Journal of Environmental Science and Natural Resources. 8 (1): 5964. 10.3329/jesnr.v8i1.24672.

[29] R. Waghmare, N. Memon, Y. Gat, S. Gandhi, V. Kumar, and A. Panghal. (2019). "Jackfruit seed: an accompaniment to functional foods". Brazilian Journal of Food Technology. 22. 10.1590/1981-6723.20718.

[30] S. B. Swami, N. J. Thakor, P. M. Haldankar, and S. B. Kalse. (2012). "Jackfruit and its many functional components as related to human health: a review". Comprehensive Reviews in Food Science and Food Safety. 11 (6): 565-576. 10.1111/j.15414337.2012.00210.x.

[31] U. B. Jagtap, S. N. Panaskar, and V. A. Bapat. (2010). "Evaluation of antioxidant capacity and phenol content in jackfruit (Artocarpus heterophyllus Lam.) fruit pulp". Plant Foods for Human Nutrition. 65 (2): 99 -104. 10.1007/s11130-010-0155-7.

[32] A. Gohain Barua and B. R. Boruah. (2004). "Minerals and functional groups present in the jackfruit seed: a spectroscopic investigation". International Journal of Food Sciences and Nutrition. 55 (6): 479483. 10.1080/09637480400015810.

[33] M. T. Hossain. (2014). "Development and quality evaluation of bread supplemented with jackfruit seed flour". International Journal of Nutrition and Food Sciences. 3 (5): 484. 10.11648/j.ijnfs.20140305.28.

[34] C. Goswami and R. Chacrabati. (2016). In "M. S. J. Simmonds and V. R. Preedy (Eds) Nutritional composition of fruit cultivars". Elsevier. $\quad 10.1016 /$ B978-0-12-4081178.00014-3.

[35] M. Hasan, M. Ahmed, and M. Miah. (2008). "Agro-economic performance of jackfruitpineapple agroforestry system in madhupur tract". Journal of Agriculture \& Rural Development. 6 (1): 147-156. 10.3329/ jard.v6i1.1672.

[36] J. L. F. Alves, J. C. G. da Silva, G. D. Mumbach, M. D. Domenico, V. F. da Silva Filho, R. F. de Sena, R. A. F. Machado, and C. Marangoni. (2020). "Insights into the bioenergy potential of jackfruit wastes considering their physicochemical 
properties, bioenergy indicators, combustion behaviors, and emission characteristics". Renewable Energy. 155 : 1328-1338. 10.1016/j.renene.2020.04.025.

[37] S. Syarbaini, A. Warsona, and D. Iskandar. (2014). "Natural radioactivity in some food crops from Bangka-Belitung islands, Indonesia". Atom Indonesia. 40 (1): 29. 10.17146/aij.2014.260.

[38] A. Mukprasirt and K. Sajjaanantakul. (2004). "Physico-chemical properties of flour and starch from jackfruit seeds (Artocarpus heterophyllus Lam.) compared with modified starches". International Journal of Food Science and Technology. 39 (3): $\quad 271-276 . \quad \underline{10.1111 / j .1365-}$ 2621.2004.00781.x.

[39] I. A. Ajayi. (2011). In: "V. R. Preedy, R. R. Watson, and V. B. Patel (Eds) Nuts and Seeds in Health and Disease Prevention". Elsevier. 10.1016/B978-0-12-3756886.10079-9.

[40] T. Theivasanthi, G. Venkadamanickam, M. Palanivelu, and M. Alagar. (2011). "Nano sized powder of jackfruit seed: Spectroscopic and anti-microbial investigative approach". Nano Biomedicine and Engineering. 3 (4). 10.5101/ nbe.v3i4.p215-221.

[41] K. Soumya, A. Krishnamoorthy, P. Patil, and M. G. Venkatesha. (2015). "Evaluation of jackfruit germplasm against jack shoot and fruit borer, Diaphania caesalis (Wlk.) (Lepidoptera: Pyralidae)". Pest Management In Horticultural Ecosystems. 21 (1): 8-10.

[42] A. Soeksmanto, Y. Hapsari, and P. Simanjuntak. (2007). "Antioxidant content of parts of Mahkota dewa, Phaleria macrocarpa [Scheff] Boerl. (Thymelaceae)". Biodiversitas Journal of Biological Diversity. 8 (2). 10.13057/biodiv/d080203.

[43] M. S. Baliga, A. R. Shivashankara, R. Haniadka, J. Dsouza, and H. P. Bhat. (2011) "Phytochemistry, nutritional and pharmacological properties of Artocarpus heterophyllus Lam (jackfruit): A review". Food Research International. 44 (7): 18001811. 10.1016/i.foodres.2011.02.035.

[44] A. Mandhare, P. Banerjee, A. Pande, and A.
Gondkar. (2020). "Jackfruit (Artocarpus heterophyllus): a comprehensive patent review". Current Nutrition \& Food Science. 16 (5): 644-665. 10.2174/1573401315666190730120759.

[45] H. B. Long, Y. F. Sun, C. Bai, and D. L. Peng. (2015). "First report of the root-knot nematode meloidogyne enterolobii infecting jackfruit tree in china". Plant Disease. 99 (12): 1868-1868. 10.1094/PDIS-04-15-0406 -PDN.

[46] A. W. Septama and P. Panichayupakaranant. (2017). "Antibacterial activity of artocarpanone isolated from Artocarpus heterophyllus heartwoods against diarrheal pathogens and its mechanism of action on membrane permeability". Journal of Applied Pharmaceutical Science. 7 (11): 64-68. 10.7324/JAPS.2017.71109.

[47] T. M. Nguyen, D. Van Binh, and E. R. Ørskov. (2005). "Effect of foliages containing condensed tannins and on gastrointestinal parasites". Animal Feed Science and Technology. 121 (2): 77-87. 10.1016/j.anifeedsci.2005.02.013.

[48] M. P. M. Haleel, K. Rashid, and C. S. Kumar. (2018). "Artocarpus heterophyllus: review study on potential activities". Research Journal of Pharmacology and Pharmacodynamics. $10 \quad$ (1): 24. 10.5958/2321-5836.2018.00005.8.

[49] D. P. Tramontin, S. E. Cadena-Carrera, A. Bella-Cruz, C. C. Bella Cruz, A. Bolzan, and M. B. Quadri. (2019). "Biological activity and chemical profile of Brazilian jackfruit seed extracts obtained by supercritical $\mathrm{CO}_{2}$ and low pressure techniques". The Journal of Supercritical Fluids. 152 : 104551. 10.1016/j.supflu.2019.104551.

[50] S. L. Jagadeesh, B. S. Reddy, G. S. K. Swamy, K. Gorbal, L. Hegde, and G. S. V. Raghavan. (2007). "Chemical composition of jackfruit (Artocarpus heterophyllus Lam.) selections of Western Ghats of India". Food Chemistry. 102 (1): 361-365. 10.1016/ j.foodchem.2006.05.027.

[51] U. B. Jagtap and V. A. Bapat. (2010). "Artocarpus: A review of its traditional uses, phytochemistry and pharmacology". Journal 
of Ethnopharmacology. 129 (2): 142-166. 10.1016/j.jep.2010.03.031.

[52] F. A. Chowdhury, M. Azizur Raman, and A. Jabbar Mian. (1997). "Distribution of free sugars and fatty acids in jackfruit (Artocarpus heterophyllus)". Food Chemistry. 60 (1): 25-28. 10.1016/S03088146(96)00294-4.

[53] B. Setiawan, A. Sulaeman, D. W. Giraud, and J. A. Driskell. (2001). "Carotenoid content of selected indonesian fruits". Journal of Food Composition and Analysis. 14 (2): 169-176. 10.1006/jfca.2000.0969.

[54] A. F. de Faria, V. V. de Rosso, and A. Z. Mercadante. (2009). "Carotenoid composition of jackfruit (Artocarpus heterophyllus), determined by HPLC-PDAMS/MS". Plant Foods for Human Nutrition. 64 (2): 108-115. 10.1007/s11130-009-0111$\underline{6}$.

[55] F. Noor. (2014). "Physicochemical properties of flour and extraction of starch from jackfruit seed". International Journal of Nutrition and Food Sciences. 3 (4): 347. 10.11648/j.ijnfs.20140304.27.

[56] S. Butool and M. Butool. (2013). "Nutritional quality on value addition to jack fruit seed flour". International Journal of Science and Research. 4 (4): 2406-2411.

[57] V. Suryadevara, S. R. Lankapalli, L. H. Danda, V. Pendyala, and V. Katta. (2017). "Studies on jackfruit seed starch as a novel natural superdisintegrant for the design and evaluation of irbesartan fast dissolving tablets". Integrative Medicine Research. 6 (3): 280-291. 10.1016/j.imr.2017.04.001.

[58] A.U. Khan and A.U. Khan. (2020). In "Infested and Healthy plant and fruit of Jackfruit".

[59] J. A. Ulloa, M. C. V. Barbosa, J. A. R. Vazquez, P. R. Ulloa, J. C. R. Ramírez, Y. S. Carrillo, and L. G. Torres. (2017). "Production, physico-chemical and functional characterization of a protein isolate from jackfruit (Artocarpus heterophyllus) seeds". CyTA - Journal of Food. $\quad 15 \quad$ (4): $\quad 497-507$. 10.1080/19476337.2017.1301554.

[60] Y. Zhang, X. Zhou, J. Zhong, L. Tan, and C.
Liu. (2019). "Effect of $\mathrm{pH}$ on emulsification performance of a new functional protein from jackfruit seeds". Food Hydrocolloids. $93 \quad$ : 325-334. j.foodhyd.2019.02.032. 